\title{
Abortion in Israel: Community, Rights, and the Context of Compromise
}

\section{Noga Morag Levine}

In contrast to American understandings of abortion as a uniquely tragic dilemma, the Israeli abortion issue is a tangential controversy in a larger debate over the relationship between the state's national and democratic identity. The divergent paths of abortion politics in Israel and the United States reflect important differences in underlying religious doctrines, geographical size, feminist ideologies, and the immediacy of other social cleavages. More profoundly, the two abortion stories are the product of distinct understandings of the mutual obligations between citizens and their state and of the relationship between individual and collective rights and duties. While these differences may account for the capacity of Israeli activists on both sides to forge pragmatic compromises, the stability of these policies is uncertain both because of changing Israeli priorities and the import of American conceptions of the abortion dispute.

The strategic and moral desirability of abortion compromises is a current and contested question among activists on both sides of the American abortion divide. The deepening scars inflicted by this controversy on American public life have prompted a search for rhetoric and policy formulas that would defuse the "clash of absolutes" and allow opposing sides to split the difference. ${ }^{1}$ At least in part, this search has been inspired by the relative

Noga Morag Levine is a Ph.D. candidate in the Jurisprudence and Social Policy Program, University of California at Berkeley. The author wishes to thank Orit Kamir and two anonymous reviewers for helpful comments and Tamar Marag, Penina Morag-Talmon, and Dori Pinto for crucial assistance in gathering materials. An earlier version was presented at the 1993 annual meeting of the Law and Society Association, Chicago.

1. The term "clash of absolutes" is taken from Lawrence Tribe, Abortion: The Clash of Absolutes (New York: Norton, 1990) ("Tribe, Abortion"). Tribe's specific compromise proposal focuses on greater social attention to pregnancy prevention and the availability of contracep-

tives. Others have emphasized the need for dialogue and empathy toward the positions of 
calm of abortion politics elsewhere and a growing sense that domestic incarnations of this dispute may not be inevitable.

An important contribution to this debate and to the comparative search for alternatives has been Mary Ann Glendon's study of the legal norms governing abortion in 20 Western countries. ${ }^{2}$ Glendon found American legal and political responses to abortion exceptional and extreme and attributed this uniqueness to the impact of individualism and rights discourse in the United States. She suggested that the constitutionalization of the abortion dispute has prematurely cut the social debate and argued that state legislatures, rather than the Supreme Court, are the appropriate forum for the normative accommodation that abortion demands. This call has recently been echoed by Roger Rosenblatt, ${ }^{3}$ who endorsed both Glendon's American exceptionalism thesis and her advocacy of a legislative middle ground patterned after European abortion statutes.

The pertinence of foreign compromises to the American abortion dispute has been debated on both substantive and methodological grounds. While some readers questioned the normative coherence and political feasibility of the statutory solutions Glendon envisions, ${ }^{4}$ others pointed to the limited data she consulted and the absence of social science and social context from her research. These methodological objections related both to the

both sides; see, e.g., Ruth Colker, "Feminism, Theology, and Abortion: Toward Love, Compassion, and Wisdom," 77 Cal. L. Rev. 1011 (1989); and Faye D. Ginsburg, Contested Lives: The Abortion Debate in an American Community (Berkeley: University of California Press, 1989). In the United States activists on both sides of the issue are deeply divided over the wisdom and legitimacy of compromise. The Christian Action Council has abandoned its boycott of corporate sponsors of planned parenthood in favor of an extensive network of "crisis pregnancy centers." In response to this and other compromise moves, Randall Terry, the founder of Operation Rescue, has stated that the days in which leaders from different (antiabortion) factions were gracious to one another are over: "We're taking the gloves off. We are not going to tolerate cowardice and compromise in our camp.... We want to change the face and (most important) principles of the pro-life movement-God is, and he has spoken." Lynn Smith, "Bowed but Unbroken?" Los Angeles Times, 22 March 1993, p. E1. Similar divisions are currently apparent in the pro-choice movement, primarily with regard to the Freedom of Choice Act and the nature of the concessions necessary for its passage. See, e.g., Robin Toner, "Success Spoils Unity of Abortion Rights Groups," N.Y. Times, 20 April 1993, p. A16.

2. Mary Ann Glendon, Abortion and Divorce in Western Law (Cambridge: Harvard University Press, 1987) ("Glendon, Abortion and Divorce").

3. Roger Rosenblatt, Life Itself: Abortion in the American Mind (New York: Random House, 1993).

4. Lawrence Tribe has warned against the incompatibility between Glendon's solutions and fundamental American values and warned against the "unacceptably high toll" her approach would exact "on confidence in the rule of law and in the integrity of the legal system as a whole." Tribe, Abortion 73-74. Richard Epstein questioned the normative foundations of Glendon's approach and argued that her effort at compromise lacks logical coherence. Richard Epstein, Book Review: "Rights and 'Rights Talk," "105 Harv. L. Rev. 1106, 1121 (1992). Arguments against the political feasibility of Glendon's model have focused on the improbability of abortion compromises under the anti-abortion tendencies of many state legislatures; Jane Maslow Cohen, Review Essay: "Comparison-Shopping in the Marketplace of Rights," 98 Yale L.J. 1235, 1253 (1989). On the irrelevance of Glendon's compromise proposals to the concerns of those who care most deeply about abortion, see Sylvia A. Law, "Abortion Compromise-Inevitable and Impossible," 1992 U. Ill. L. Rev. 921, 938-39. 
accuracy and completeness of the European stories themselves 5 and to their relevance to American abortion dilemmas. Comparative abortion prescriptions, suggested Martha Fineman in a review of Glendon's book, can be persuasive only when they account for differences in the political culture, religious beliefs, and feminist discourse in which foreign abortion models are situated. Fineman argued that where such serious attention to context is missing, there is little evidence for the proposition that "European solutions can be transplanted and their stories translated for Americans."6

This article aims to apply such contextual analysis to the evolution of abortion compromises in Israel. Although Israel was not one of the countries included in Glendon's study, the legislative solutions that country adopted are like those she espouses. While important religious and geopolitical factors distinguish the Israeli case from others Glendon considered, these same factors also highlight the potential for fundamental differences in the local meaning of abortion controversies. Such differences do not invalidate the search for better alternatives, but they should caution us against comparative explorations that ignore the complex interactions between law, culture, and the manifestation of social conflict.

\section{DEMOCRACY, NATIONAL IDENTITY, AND ABORTION}

Abortion is hardly the first topic to capture the attention of observers of Israeli politics. Although conflicts over abortion legislation have periodically resurfaced in the country, the subject has largely remained tangential to the Israeli public debate and the multiple social cleavages that cut across this society. ${ }^{7}$ Most often, abortion has entered Israeli politics in the context of coalition demands by orthodox parties that have included abortion restrictions among conditions for their support of various Israeli governments. In response to the threat of such legislation, opposing groups have mobilized with varying success. The result has been episodic and intermittent public attention to an issue that for the most part seems to elicit more apathy than ambivalence.

The multiplicity and intensity of other political conflicts in Israel offers a partial explanation for the relative marginality of abortion issues. Never-

5. See Heleen F. P. Ietswaart, Book Review: "Incomplete Stories," 69 Boston U.L. Rev. 257 (1989), and Leslie Pickering Francis, Book Review: "Virtue and the American Family," 102 Harv. L. Rev. 469 (1988), for the argument that Glendon's account of the Dutch, German, and French models are inaccurate on several grounds. (1988).

6. Martha L. Fineman, "Contexts and Comparisons," 55 U. Chi. L. Rev. 1431, 1433

7. For an analysis of these cleavages and current competing pressures in Israeli society, see Dan Horowitz \& Moshe Lissak, Trouble in Utopia: The Overburdened Polity of Istael (Albany: State University of New York Press, 1989) ("Horowitz \& Lissak, Trouble in Utopia"). 
theless, because of the centrality of both religious values and population policies to Israeli political life, the abortion debate's low profile may seem perplexing. Israeli national identity is founded on a precarious balance between the country's dual definition as a Jewish and a democratic state, and abortion policy touches on both sides of this equation. While the legal status of abortion is inherently tied to the unresolved debate over the role of religious Jewish law in Israeli life, the demographic implications of abortion policies are relevant to the reliance of the Jewish and democratic formula on the maintenance of a popular Jewish majority.

The puzzle created by the failure of these considerations to transform abortion into a central social dispute is compounded by the attention granted to other religious concerns. Issues such as the operation of movie theaters or public transportation on the Sabbath or the paving of a road over what may have been an ancient Jewish cemetery have repeatedly been the subject of large and often angry demonstrations. Motorists who venture on Saturday into religious neighborhoods have occasionally been stoned, and the windows of a Jerusalem restaurant that served bread on Passover were shattered. While abortion has not been ignored by religious interests in Israel, and disputes relating to its regulation do occasionally flare, the issue has not drawn the sustained attention and political efforts of these other, arguably less difficult, religion and state conflicts.

The courts, including the increasingly active Supreme Court, have had little to say on the abortion question and have never considered the legitimacy of governmental intervention in this sphere. The scarcity of abortionrelated adjudication can be attributed partly to the absence of a written constitution and judicial review empowered to invalidate legislative acts. Although the Israeli Supreme Court has increasingly invoked doctrines of fundamental values in its statutory and regulatory interpretations, the "constitutional common law" that evolved out of this process is devoid of a conception of inherent limits on state power. ${ }^{8}$ The absence of such a constitutional anchor makes the central jurisprudential questions of the American abortion debate largely irrelevant to Israeli politics. ${ }^{9}$ But it does

8. The term "constitutional common law" is taken from Amos Shapira, "The Israeli Supreme Court and Human Rights," in Daniel Elazar, ed., Constitutionalism: The Israeli and American Experiences (Lanham, Md.: University Press of America, 1990).

9. Much of this area is currently in flux. In 1992 the Israeli Knesset enacted Basic Law: Human Dignity and Freedom, 1391 S.H. 150 (1992) (in Hebrew). The law provides that no person's life, body, dignity or property shall be violated and includes, among other guarantees, protections for private domains and personal communications. Under the law such guarantees can be infringed "only by a law that conforms to the values of the State of Israel-which is a Jewish and democratic state-is directed to a worthy purpose, and only to the extent necessary." See David Kretzmer, "The New Basic Laws on Human Rights: A Mini-Revolution in Israeli Constitutional Law?" 26 Is. L. Rev. 238, 242, 248, for the argument that the new law allows for some forms of judicial review. Justice Aharon Barak, the current Deputy Chief Justice of the Israeli Supreme Court, off the bench has described the new law as a "constitutional revolution" and a new framework for the invalidation of some Knesset laws. Aharon 
not explain why in contrast to prevailing tendencies to involve the highly accessible Supreme Court in multiple spheres of public life, ${ }^{10}$ Israelis have rarely called for judicial interventions in abortion. Instead, a set of de facto compromises has allowed for a tentative regulatory regime that has largely defused the abortion conflict. The ideological and political factors that sustain this compromise and that distinguish Israeli abortion politics from their American counterpart are developed below.

\section{IDEOLOGIES AND ACTORS}

\section{A. Abortion in Jewish Religious Law}

While religious doctrines are almost always intertwined with the evolution of abortion politics, Jewish abortion doctrines bear particular relevance to Israeli abortion controversies because of the complicated and unresolved relationship between religious and state law in that country. In the absence of constitutional boundary demarcations, a set of ad hoc solutions and deferred decisions have defined the search for mediation between Jewish and democratic values. ${ }^{11}$ While in certain areas, most notably marriage and divorce, religious norms were officially incorporated by state law, much of this sphere remains governed by extralegal solutions. The avoidance of law has served to defuse potential conflicts between the religious and secular systems. But it has also resulted in little political accountability and pervasive gaps between explicit and implicit religion and state policies.

Jewish attitudes toward abortion are nuanced and open to conflicting interpretations. Jewish abortion norms derive from Biblical and Talmudic texts that address the question only indirectly. ${ }^{12}$ Vague and at times inconsistent, these sources have become the basis of a religious doctrine characterized by significant divisions over the nature, scope, and origin of the prohibition on abortion. What unites these diverse views and distinguishes

Barak, "The Supreme Court's Weighty Task" Jerusalem Post, 24 May 1992. The Israeli Supreme Court is yet to rule on this question.

10. The Israeli Supreme Court, sitting as a High Court of Justice, exercises original jurisdiction over petitions against governmental and administrative actions.

11. Horowitz \& Lissak, Trouble in Utopia.

12. The primary paradigm case and the sole biblical reference in this context is Exodus 21:22-23. The passage describes a situation in which a pregnant woman is accidentally injured as a result of a fight between two men. The text distinguishes between a situation in which no catastrophe occurs and the man is assessed a fine and one in which a catastrophe does occur and life is given for life. Rabbinic interpretations have viewed "catastrophe" as harm to the mother and thus concluded that the damage to the fetus was a civil and not a criminal wrong. Talmudic and Rabbinical discussions offer examples relating to a fetus who endangers a woman's life during childbirth, a pregnant woman who is to be executed, and the legal capacity of a fetus to receive gifts and acquire property. See Dena S. Davis, "Abortion in Jewish Thought: A Study in Casuistry," 60 (2) J. Am. Acad. Religion 313 (1992), and David Kramer, "Jewish Ethics and Abortion," 8 (1) Tikkun 55 (1993). 
the Jewish position from its Catholic counterpart is the clear precedence accorded to maternal life over the life of the fetus. Questions of ensoulment or salvation after death are not relevant to Jewish theology in this area, and the inferior life claim of the fetus is reflected in a religious requirement that abortions be performed to save the life of the mother. ${ }^{13}$

In contrast to the unbending divisions imposed by equating abortion to murder, Jewish debates of the issue revolve around the flexible distinction between necessary and unnecessary abortions. While some rabbis would justify abortions only when the woman's life is in danger, others are willing to extend religious exemptions when continuation of the pregnancy threatens the woman's physical or psychological well being. Although these differences can have crucial practical implications and are grounded in divergent views of the gravity of abortion, they represent points along a continuum defined by contextual understandings of religious duties in this sphere. ${ }^{14}$

The supremacy of maternal life in Jewish religious law has fractured the alliance U.S. Orthodox Jewish organizations have had with the anti-abortion movement and has led to expressions of ambivalence over the absolutist ideology of anti-abortion forces..$^{15}$ Similar sentiments have allowed for legislative compromises in the Israeli context that largely fit within the case-by-case approach implied by Jewish law. Although the terms and implementation of the statutory exemption categories continue to be targets of religious unrest, there is little in the underlying theology that evokes the fervor and commitment of the American anti-abortion movement. ${ }^{16}$

13. The supremacy of maternal life to that of the fetus continues until the fetus's head or major body part has emerged. After the emergence of the head, the fetus assumes human status in most respects. See Immanuel Jakobovits, Jewish Medical Ethics (New York: Philosophical Library, 1959).

14. See David M. Feldman, Birth Control in Jewish Law (New York: New York University Press, 1968).

15. Speaking to this issue, Rabbi Pinhas Stolper, executive director of the Union of Orthodox Jewish Congregations, stated in 1989: "We do not identify with those groups that feel all abortion is murder. ... Unlike the Catholic position ... Halacha [Jewish law] takes different views of the fetus at different times of development. In the Jewish view, the supreme need is to consider the life, health and well being of the mother." Walter Ruby, "The Organized American Jewish Community Takes a 'Freedom of Choice' Line on Abortion," Jerusalem Post, 14 March 1989, p. 7. Similar sentiments were expressed by Agudath Israel of America, an ultra Orthodox lobbying group which filed an anti-abortion brief in Webster v. Reproductive Health Services, 492 U.S. 490 (1989), when it refused to support a bill that would have excluded religiously mandated abortion from religious freedoms protected under another proposed federal statute from state encroachment. "Agudath Israel Objects to Religious Freedom Act," Jewish Advocate, 28 Feb. 1992, at 6.

16. A 1974 report issued by a committee which drafted revisions to the Israeli abortion code included two rabbinical opinions on the Jewish status of abortion. Both opinions link the permissibility of abortion to the age and circumstances of the pregnancy, and both suggest a disapproving yet flexible attitude. Report of the Committee for the Study of the Ban on Induced Abortions, 17 (4) Briyut Hatsibur 425, 495-505 (1974) ("Committee Report, Briyut Hatsibur") (in Hebrew). 


\section{B. Ideological Commitments and Anti-Abortion Activism}

If Israelis are divided over the religious content of their identity, the need for a Jewish majority in the state is widely accepted by its Jewish citizens. Such a majority is considered to be the linchpin in the state's Jewish democratic balance and is at the heart of Israeli struggles over the future of the occupied territories. While the spectrum of Israeli politics is defined by alternative emphasis on particularistic and universal values, the respective visions of both sides depend on the stability of a Jewish popular majority. Although there is little consensus on the impact demographic problems ought to have on national abortion policies, the argument from demography, in contrast to the argument from religion, has broad social resonance. The result has been an anti-abortion coalition that has chosen to emphasize collective national values and in which the religious affiliation and motivation of many of its activists have been largely suppressed.

The primary anti-abortion voice in Israel has been Efrat-the Right to Life Association for the Encouragement of Increase of Birthrate among the Jewish People. Efrat was incorporated in 1962 in response to statistical evidence showing declining Jewish birth rates in the country, limited immigration, and differential fertility of Arabs and Jews. During the 1960s the organization's primary focus was on the creation of a normative social climate that would emphasize the "national obligation to care for the future of the people and its numeric strength" and the creation of social policies that would encourage and reward large families. ${ }^{17}$ The first Efrat newsletter, published in 1962, made only implicit reference to abortion and did not list it among the organizational goals and bylaws cited in that issue. The subject was directly addressed for the first time in a 1965 newsletter that detailed Efrat's role in pressuring the Attorney General toward stricter enforcement of the abortion law and marked the beginning of growing organizational emphasis on abortion policies.

This process culminated in the early 1980s with a pronounced shift in the rhetorical style employed by the organization. It was during that time that the words "Right to Life" were added to Efrat's official title, and its newsletter began to emphasize fetal rights by using medical textbook pictures of abortion and publishing articles like "Four Ways to Kill an Unborn Child" and the "Diary of an Unborn Child." 18 The American anti-abortion movement was quite clearly the inspiration for this change, whose conduit appears to have been American Orthodox immigrants who became in-

17. See Efrat, November 1962, p. 4 (in Hebrew). The cover of this newsletter features a picture of a couple with their ten children. The caption reads "Happiness and Strength in the home of the Tawik family. May everyone be like them."

18. 12 Yedion-A Quarterly for Family Affairs and the Encouragement of Procreation among the Jewish People (translated title), pp. 24-25 (1983) ("Yedion") (in Hebrew). The publication is an Efrat newsletter. 
volved in Israeli abortion politics during that time. ${ }^{19}$ Clear reference to the American inspiration was made in a 1985 Efrat newsletter which cited the American anti-abortion movement as a model for imitation and which featured a picture of Ronald Reagan on its cover. The new emphasis on fetal rights may also have been the product of recognition of the growing individualism in Israeli society and the limited impact of demographic exhortations on parenthood decisions. Appeals that during the 1960s were couched in the language of national obligation and collective responsibilities were transformed in the 1980s into moral claims about fetal life. In both cases there was little if any reference to religious values or Jewish law.

The absence of religious rhetoric in Efrat's campaign is in part a product of a tactical choice designed to insulate the abortion debate from the antireligious animosities of many secular Israelis. Speaking directly to this issue, an editorial in a 1984 Efrat newsletter stated: "We should develop ideas and present facts before the general public. We should not use religious arguments in front of them. There are plenty of philosophical, moral, demographic and health reasons to oppose abortion. . . . Religious justifications may lead the secular public to think that this is just another religious observance." 20 But the diversity of arguments Efrat advanced in its antiabortion campaign was more than a facade for a hidden, exclusively religious agenda. It reflected the varied positions of those who assembled in its coalition, the frequent alliance between nationalist and religious interests in Israel, and the less than homogenous view of Jewish religious law on this subject. The result was an anti-abortion campaign that focused on "unnecessary abortions" and, in contrast to its corollary American movement, was not propelled by one overarching claim. While the multiplicity of arguments advanced by Efrat helped it win support in broad quarters, it has also defused the intensity of the debate and bypassed the dichotomous divisions that have characterized the American abortion struggle.

An even more pronounced retreat from ideological confrontation is evident in the philosophical direction adopted by Just One Life, a private organization established in 1986 with the goal of offering social and financial assistance to pregnant women. Unlike Efrat, Just One Life opposes legislative restrictions on abortion and its activists emphasize the centrality of a woman's choice to decisions in this sphere. ${ }^{21}$

19. One such immigrant, a statistician named Haim Hazan was appointed under pressure by Agudat Israel, an ultra orthodox political party, as special abortions consultant to the Minister of Health during the early 1980s.

20. Shlomo-Yona Tuaf, "Religious Justifications Ought Not Be Used in Front of the General Public" (translated title), 17-18 Yedion 3 (1984) (in Hebrew).

21. Susan Poizner, "The Abortion Debate Goes On," Contact (Jerusalem Post Magazine), 12 July 1991, and Carl Alpert, "Israel Has Abortion Problems Too," Greater Phoenix Jewish News, 31 Jan. 1992, p. 8. 


\section{Ideological Commitments and Abortion Services Activism}

A similar diversity in organizational structure, tactics, and ideology exists on the opposite side of the Israeli abortion question. ${ }^{22}$ Among those active on behalf of abortion rights and abortion services are the Social Workers Union, mainstream women's organizations, the Israeli Planned Parenthood Association, the Association for Civil Rights, pregnancy counseling centers, and the Israeli feminist movement. The bulk of these groups' efforts have centered on protection of the current legal status quo and the provision of information and support services required for successful maneuvering of the obstacles it poses. Few claims are grounded in reproductive freedoms and a right to choose and liberal arguments have focused on the terms of governmental intervention in abortion, not on the basic legitimacy of such regulation. The result has been an abortion services movement largely devoid of rights discourse and characterized by a significant amount of sympathy for the demographic concerns of the other side. ${ }^{23}$

The practical absence of a reproductive choice agenda in the Israeli abortion debate reflects the general marginality of the Israeli feminist movement. Originally organized as a political group in the late 1970s by American immigrants, this movement has struggled to gain a foothold in Israeli politics and its language and concerns remain foreign to most Israeli women. Although recent years have shown the formation of an increasingly vocal women's lobby and growing feminist consciousness on the part of traditional women's groups, activists in these organizations repeatedly lament the difficulties they encounter in mobilizing support among women. This political passivity is the product of multiple factors ranging from the influence of traditional Middle Eastern cultures to the effects of military life and values on the place and self-perception of women in society. But it is also the product of the overwhelming impact of the fundamental dispute over the goals and terms of Israeli-Palestinian relations and the willingness of women on both sides of this divide to defer gender-equity issues to a later date. ${ }^{24}$ Even if the improving prospects for peace in the Middle East were to result in greater emphasis on gender equality, such efforts would not begin with abortion. Israeli family law, which delegates almost all marriage and

22. Delila Amir \& D. Navon, The Politics of Abortion in Israel (translated title) 50 (Tel Aviv: Pinchas Sapir Center for Development, Tel Aviv University, 1989) ("Amir \& Navon, Politics of Abortion") (in Hebrew).

23. Id. at 17-37.

24. Both the magnitude of alternative cleavages and the marginality of gender to the political identity of Israeli women were clearly reflected in the political fortunes of a party that ran on an exclusive women's rights platform during the 1992 general elections. The Party received a total of 2,886 votes, or $0.1 \%$ of the total votes cast, an electoral result that placed it just below a party that promoted the professional interests of taxi drivers and far short of the 39,253 votes necessary for representation in the current Knesset. Asher Wallfish, "Final Election Vote Tally Marginally Adjusted," Jerusalem Post, 29 June 1992, p. 3. 
divorce questions to the religious courts, is notoriously unfair to women who depend on their husbands' consent for divorce. ${ }^{25}$ This and other personal status questions, rather than abortions, would be the most likely targets of gender-based mobilization in Israel.

As is evident from the above picture, the Israeli abortion debate can be characterized by the absence of a strong ideological component in both sides. In contrast to the gulf that separates pro-choice and anti-abortion activists in the United States, the spectrum of disagreement in Israel is significantly narrower. Calls for absolute prohibitions on abortion or abortion on demand are virtually absent, and political struggles have largely focused on attempts to restrict "unnecessary abortions" or campaigns to enlarge the range of legal circumstances under which abortion ought to be permitted. To this extent, abortion in Israel seems to accord with the conciliatory pattern and compromise solutions Glendon ascribed to European abortion politics. ${ }^{26}$ The following section presents an analysis of the origins and terms of this compromise.

\section{LEGISLATIVE BATTLES AND INFORMAL COMPROMISE}

Official Israeli abortion statistics show an average of 15,427 annual abortions or a rate of between 15 and 20 per thousand women of childbearing age. ${ }^{27}$ In addition, private, illegal abortions are provided by physicians in clinics. There is no reliable data on the frequency of such private abortions, but 5,000-6,000 are commonly quoted figures..$^{28}$ The significance of the distinction between legal and illegal abortions and the evolution of legislative compromises in this area are discussed below.

\section{A. The Old Abortion Statute and the Impetus for Reform}

In accordance with cross-national trends toward abortion law reform during the 1970s, Israeli abortion statutes were amended in 1977. However,

25. Under Jewish law, divorce depends on the consent of both parties. However, religious sanctions against extramarital relations drastically discriminate against married women. As a result, women are significantly disadvantaged by the mutual consent requirement.

26. Glendon, Abortion and Divorce (cited in note 2).

27. Between 1979 and 1990, the lowest number of recorded hospital abortions was in $1981(14,514)$ and the highest in $1982(16,829)$. Latest available statistics are for 1991 and show a total of 15,509 hospital abortions. Statistical Abstract of Israel, No. 42, sec. 3.21 (1991).

28. Lotte Salzberger, Sarah Magidor, Amy Avgar, \& Janet Baumgold-Land, "Patterns of Contraceptive Behavior Among Jerusalem Women Seeking Pregnancy Counselling 1980-1989" at 14 (Hebrew University of Jerusalem, Paul Baerwald School of Social Work 1991). ("Salzberger et al. 'Patterns of Contraceptive Behavior' "). Although instances of medical malpractice in the private abortion area have been the object of significant media attention, most private abortions are performed in safe and professional medical settings. Id. at 15. 
in contrast to the impetus for most such reforms during that era, significant support for the new Israeli legislation came from those who wanted to restrict rather than liberalize the availability of abortions. The reform effort was largely propelled by a search for greater governmental commitment to abortion law enforcement and frustration with the total irrelevance of what was until then a categorical legal ban on abortions. ${ }^{29}$

Israel's first abortion statute originated in British mandatory legislation and was adopted together with most of the mandatory criminal code when the state became independent in 1948. The law criminalized the performance of all abortions, with the exception of the judicially recognized defense of medical necessity. Rarely enforced during the British mandate, the law remained a dead letter under its Israeli incarnation. ${ }^{30}$ Between 1952 and 1963 this de facto nonenforcement policy was strengthened by Attorney General directives that limited prosecution to abortions in which the woman's consent was in doubt or where negligence or injury were involved. These directives were rescinded in 1963 when their legality was contested in early attempts to restrict the availability of abortions. Despite this change and temporary expectations of a clamp down on abortion providers, ${ }^{31}$ the law continued to be ignored, and the private abortion market flourished. In addition, de facto abortion approval procedures were implemented by the largest labor union sick fund, which performed and often funded the abortions it approved. ${ }^{32}$

The first call for institutionalization of the ad hoc procedures appeared in the 1966 report of a Commission for the Study of Birthrate Problems, appointed in response to growing concerns over declining population growth and the differential fertility of Arabs and Jews. The commission cited abortions among the factors contributing to the nation's declining birth rates, but its members failed to agree on the policy implications of this finding. While four of the eight-member commission opposed greater state intervention in abortion, the remainder called for statutory reform aimed at creating more realistic and enforceable legal norms. The primary strategy they promoted was legalization of the semiofficial arrangements, most notably hospital abortion approval committees. ${ }^{33}$ Such a step, argued the commission's majority report, would reintroduce a measure of governmental control into an area where legal norms had largely ceased to matter. This recommendation, like many of the others included in the commission's re-

29. Amir \& Navon, Politics of Abortion 50.

30. See Dan Shnit, "Induced Abortion in Israeli Law," 15 Israeli Yearbook on Human Rights 155 (1985).

31. A headline in the 31 Aug. 1962 edition of the Israeli paper Yediot Ahronot stated, "Doctors Who Perform Abortions Will Have to Go Underground, Can Expect Prosecutions and License Revocations." Cited in 4 Efrat 44 (1965).

32. Salzberger et al., "Patterns of Contraceptive Behavior" at 12.

33. Dov Friedlander, "Population Policy in Israel," in Bernard Berelson, ed., Population Policy in Developed Countries (New York: McGraw Hill, 1974). 
port, was not implemented at the time. But the direction it outlined was the one ultimately followed when the Israeli abortion law was finally amended in 1977.

\section{B. Legislative Reform}

Those who sought legal reform out of a desire for greater abortion law enforcement were joined in the early 1970s by the fledgling Israeli feminist movement and a short-lived political call for abortion rights. In the Knesset (the Israeli parliament) this call was largely the work of Marcia Freedman, a recent American immigrant and a newly elected legislator. Freedman submitted in 1974 a proposed bill for free abortion on demand and was instrumental in organizing feminist demonstrations on its behalf. Israeli women, for the most part, showed little interest in this legislative effort and were ambivalent about upsetting the status quo under which abortions, though illegal and often expensive, were widely available. ${ }^{34}$ The diverse political pressures for reform led to the appointment in 1972 of a new governmental committee for the study of the legal ban on abortions. The committee's report reviewed the legal, medical, social, and religious aspects of abortion policy and included a draft revision to the abortions statute. ${ }^{35}$ The primary model for the proposed bill was the 1967 British Abortion Act, which did not create a general right to abortion but outlined the conditions under which abortions will be exempted from criminal sanctions. Primary among these conditions was the good faith opinion of two registered medical practitioners that continuance of the pregnancy would harm the physical or mental health of the woman or her children or that there is substantial risk that the child would be born with serious abnormalities. While the draft Israeli law produced by the committee was based on such partial legalization of abortion, its version differed from the British model in one significant respect. Whereas in Britain the concurrence of two medical practitioners was sufficient to legalize an abortion, the new Israeli bill allowed for greater bureaucratic control by conditioning legal abortions on the approval of hospital committees.

The draft abortion law was submitted to the Knesset in 1975 by 24 legislators from both opposition and coalition parties. After a lengthy and acrimonious political debate, the law was approved in 1977 and went into effect in 1978. ${ }^{36}$ The law imposed a sanction of five-year imprisonment on the deliberate termination of pregnancy but exonerated from criminal liabil-

34. Lesley Hazleton, Israeli Women: The Reality behind the Myths (New York: Simon \& Schuster, 1977).

35. Committee Report, Briyut Hatsibur (cited in note 16).

36. The law is codified as Penal Amendment (Interruption of Pregnancy) 1977, 31 Laws of the State of Israel 82. 
ity licensed gynecologists who performed the abortion in a recognized medical institution after it was approved by a pregnancy termination committee. Such committees, to consist of two physicians and a registered social worker, were to operate in and under the supervision of recognized medical institutions.

Committees were authorized to approve abortions under one of the following circumstances: (1) the woman is under marriage age (17) or over 40; (2) the pregnancy resulted from relations prohibited by the criminal law, incestuous relations, or extramarital relations; (3) the child is likely to have a physical or mental defect; (4) continuance of the pregnancy is likely to endanger the woman's life or cause her physical or mental harm; (5) continuance of the pregnancy was likely to cause grave harm to the woman or the children owing to the difficult family or social circumstances of the woman and her environment.

\section{The Socioeconomic Conditions Clause}

The most controversial element in the new law was the provision, patterned after the British law and known as the social clause, that allowed committees to base abortion approvals on a woman's social environment and economic circumstances. The clause was directed at married women who did not fall under any of the other exemption categories. It was hotly contested in the debates of the abortion prohibitions committee, and its inclusion in the bill this committee ultimately produced proved to be crucial in gaining the support of women's groups who were ambivalent about the need and wisdom of legislative reform and the potential for stricter enforcement against private abortion providers.

The primary victims of the ambiguous legal status of abortions under the old Israeli law were women who could not afford abortions in the illegal but relatively safe $\mathrm{e}^{37}$ private market and did not qualify for them under the limited medical categories recognized by the sick fund committees. Most women who came before these committees were of low socioeconomic background, ${ }^{38}$ and it was they who would gain the most from a broadening of recognized grounds for abortion. Looking back to her legislative efforts in this area, Ora Namir, an active proponent of the bill in the late 1970s and the current Minister of Labor and Welfare, stated:

The abortion law was primarily enacted because of the social conditions provision. Well off women, including religious well off women, don't need laws, they know where to go and how to protect themselves. We thought it was important, beyond the question of principle,

37. See Salzberger et al., "Patterns of Contraceptive Behavior" at 12.

38. Committee Report, Briyut Hatsibur at 467. 
in order to aid a population of women that have difficulty dealing with the conditions of their lives. ${ }^{39}$

In sharp contrast to the situation in the United States where poor women's access to abortion was the primary casualty of the de facto compromises that have emerged in this area, ${ }^{40}$ Israeli abortion legislation offered the opposite trade-off. While the law imposed significant restrictions on the legality of abortions, it also held the promise of greater public funding for the procedure. ${ }^{41}$ In Israel such trade-offs are a natural extension of traditional commitments to collectivism and egalitarianism. Although pervasive gaps between ideology and practice have long characterized Israeli public life, these values remain central to the country's national ethos. ${ }^{42}$ The Israeli abortion compromise clearly accords with such conceptions of interdependence between individuals and their state. While it assumes the permeability of individual autonomy in this sphere, the legal model it posits is one in which the power to regulate abortions and the duty to provide for them are intertwined.

A few months after the 1977 passage of the abortion law, in an unrelated political development, control of the government shifted from the long-ruling Labor Party to its Likud rival. Coalition negotiations between the Likud and its ultra-Orthodox partners resulted in a number of religious law concessions, primary among them the abolition of the "social conditions clause" from the list of circumstances justifying abortion approvals. Despite widespread opposition to this step, ${ }^{43}$ the clause was eliminated in 1980, in a 55-50 vote, less than two years after it first came into effect.

39. Protocols of Knesset debate on amendment 30 to the criminal code, 181st meeting of the 12th Knesset, 28 May 1990.

40. Since 1977 Congress has severely restricted federal Medicaid funding for abortions in a series of amendments to congressional appropriations bills known as the "Hyde Amendment." The Supreme Court upheld the Amendment in Harris v. McRae, 448 U.S. 297 (1980). The subject of public funding for abortion is currently again on the agenda in the context of President Clinton's plans for health care reform.

41. Government-subsidized sick funds are the primary vehicle for public funding of abortion under the current law. Such funding is available only when abortions are approved for a medical cause, i.e., fetal abnormalities or age of the pregnant woman or physical or emotional risk to her. When abortions are legally approved under other exemption categories, funding for needy women can sometimes be obtained from various public welfare organizations. The price for a hospital abortion is around $\$(U S) 350$ (1,200 Israeli shekels).

42. Shapiro Yonathan, Democracy in Israel (translated title) (Ramat-Gan: Masada, 1977) (in Hebrew).

43. The social workers' union was among the most vocal opponents of the cancellation of the social clause which until then created a professional rationale for the presence of social workers in pregnancy termination committees. In an article focusing on the message of social equality implicit in the social clause, the then secretary general of the social workers union stated: "The pregnancy termination law is an important and essential social statute, whose cancellation, and especially the cancellation of the social clause provision in it, will constitute severe social injustice." Kadman Yitzhak, "Pregnancy Termination from a Social Perspective," 3 Hevra Urvacha 320, 322 (1979) (in Hebrew). 
The repeal of the social conditions clause undermined the primary rationale for liberal support of the new law, and was seen by these groups as a significant setback. To this day this legislative defeat retains important symbolic meaning, and efforts to reintroduce the clause are occasionally undertaken. ${ }^{44}$ However, as is often the case with legislated restrictions on abortion, the cancellation of the social clause had little impact on the number of abortion approvals which, after a temporary dip, soon returned to their preamendment levels. ${ }^{45}$ No longer able to justify an abortion by explicit reference to the number of children in a household or the economic conditions of the family, abortion committees invoked alternative exemption categories, most notably physical or mental risk. ${ }^{46}$ The result was a new ad hoc accommodation, in which formal limitations on justified abortions were complemented by an enforcement policy that responded to the needs of those who did not easily fit into the state-approved categories. The key to this accommodation was the flexibility and discretion the law accorded the abortion committees and the normative diversity this institutional autonomy has been able to support.

\section{Committee Discretion and Diversity}

As indicated before, abortion approval committees predated the passage of the 1977 law and were utilized in informal procedures. The 1977 law legitimated this model, expanded its definition, and accorded it a pivotal role in the mediation of the conflicting interests it sought to accommodate.

44. The latest occurred in October 1993 when in an effort to take advantage of a rare absence of religious partners in the governing coalition, three bills proposing the reinstatement of the social clause were brought before the Knesset. Proponents of this move presented it as an important first step toward broader elimination of abortion restrictions and a bar against the proliferation of illegal abortions. Despite these goals, women's organizations did not mobilize on behalf of this effort. While this decision stemmed in part from recognition that the sensitive state of the peace process makes this a particularly inopportune time for actions that would undermine religious support of the government, it also reflected reluctance, on the part of these groups, to expend political capital on a symbolic battle with few practical implications. The bills failed in a preliminary hearing when both major parties refused to support them. See protocol of 37th meeting of the 13th Knesset, 20 Oct. 1993.

45. According to Israeli governmental statistics, in 1979 there were 15,925 hospital abortions. In 1980, the year in which the social clause was eliminated, there was a $7.6 \%$ decline in the number of hospital abortions, which totaled 14,708. However, by 1982 the number of hospital abortions increased by $16 \%$ and reached 16,829, and in 1984 the number was 18,948 . Whereas in $1979,40 \%$ of hospital abortions were approved under the social clause and $8.2 \%$ were performed under the physical or psychological risk clause, in 1980, the year in which the social clause was eliminated, $35.1 \%$ of abortion approvals were granted under the medical risk clause. Israeli Central Bureau of Statistics figures cited in Amir \& Navon, Politics of Abortion 56 (cited in note 22).

46. The latest detailed statistics of the distribution of committee approvals by clause are for 1989. During that year, of a total of 15,915 hospital abortions, 1,986 were justified by the woman's age, 6,715 were recorded as out-of-wedlock pregnancies, 3,022 were attributed to a malformed fetus, and 3,994 fell under danger to a woman's life. Approval clauses for an additional 198 abortions were not recorded. Statistical Abstract of Israel, No. 42, sec. 3.23 (1991). 
The pregnancy termination committees established by the law were granted wide discretion and little direction as to the values their decisions ought to serve. The Israeli law offers no rationale for the general prohibition it imposes and does not identify the claims it seeks to balance. There is no reference to the status of the fetus, its rights, or those of the pregnant woman. There are no statutory or administrative parameters for the severity of the risk to the fetus or pregnant woman that would justify an abortion and no definition of the nature of the mental harm the law envisioned.

Finally, even for categories that appear to offer little room for independent judgment, such as unmarried relations or age, committees maintain discretionary authority. Under the law the "committee may ... approve the interruption of pregnancy if it considers it justified on one of the ... grounds." Thus satisfaction of one or more of the enumerated legal grounds allows but does not obligate a committee to approve an abortion. Although the reasonableness of committee decisions could probably be subject to judicial review, ${ }^{47}$ petitions on this issue have not come before the Israeli High Court of Justice. The absence of such petitions should probably be attributed both to the general propensity of committees to approve abortions and to the legal capacity of women who were denied an abortion by one committee to bring their case before another ${ }^{48}$ Here and in the interpretive responses of committees to the repeal of the social clause, the wide discretion accorded under the law to the abortion committees has served to defuse what could have been significant abortion conflicts.

Committees may operate in any hospital approved for this purpose by the Ministry of Health, and their membership is determined by hospital management. In 1991, 27 such committees operated in private and public hospitals throughout the country. ${ }^{49}$ Women may choose to apply to any committee in the country, and this choice may have important bearing on their chance for abortion approval. Despite uniform Ministry of Health regulations, studies of the procedures and policies employed by the committees show significant variation in the frequency at which committees are convened, the amount of paperwork and bureaucratic red tape required of applicants, and the tactics employed to discourage termination of pregnancy..$^{50}$ Committees also differ in the impact of the stage of the pregnancy on their approval policies, the strictness with which they interpret the presence of risk to the woman, and their willingness to approve abortions under the extramarital relations clause.

47. Dan Shnit, 15 Israel Yearbook on Human Rights at 155, 158 (cited in note 30).

48. The Court did consider a petition from a husband who contested a decision by a pregnancy termination committee to approve his wife's abortion. The husband's appeal was rejected on the ground that he did not have a vested right in the approval process. See C.A. (Civil Appeal) 413/80, Plonit v. Ploni, 35(3) P.D.57. Cited in id. at 175.

49. Salzberger et al., "Patterns of Contraceptive Behavior" at 13 (cited in note 28).

50. Id. at 13 . 
The lack of intercommittee consistency is the product both of the personal beliefs of senior doctors and administrators in each hospital and of the hospital's institutional affiliation and general worldview. ${ }^{51}$ Some Orthodox hospitals have refused to participate in the implementation of the 1977 law, did not establish committees, and do not perform abortions. Others approve and perform abortions only when continuation of the pregnancy would severely endanger the health of the woman. In contrast, other hospitals and committees, particularly those operating in private hospitals in the Tel Aviv area, have developed a reputation for liberal abortion approval policies. Because a woman's chance for approval is highly dependent on the identity and ideological commitment of the committee she approaches, information on committee reputation is of crucial importance. Pregnancy counseling services are a primary mechanism for the dissemination of this knowledge, and they advise women as to which hospital committee is more likely to approve their request. Such counseling is particularly important in Jerusalem where there is a high concentration of religious hospitals and few sympathetic committees and where women are often unaware of the availability of accessible liberal committees in Tel Aviv, about 50 miles away. ${ }^{52}$

Although women in Jerusalem and in small settlements and towns throughout the country are inconvenienced by the scarcity of approval committees in their locales, travel time to the nearest liberal pregnancy termination committee rarely exceeds more than two hours. Unlike the United States, where a delegation of the abortion question to the states would necessarily result in long journeys and severe hardships for many women, Israel's small size has mediated the effects of the normative diversity created under the committee structure. Institutional autonomy has allowed religious hospitals to form their own abortion policies and has isolated the government from direct accountability for some committees' liberal practices. While this arrangement and the diversity it supported have been the key to the relative calm of Israeli abortion politics, the long-term stability of this informal solution is less than clear.

\section{E. Governmental Control and Private Hospital Committees}

The wide variation in the approval policies of the different committees and the failure of the social clause repeal to reduce the number of abortions

51. Memorandum from attorney Netta Ziv Goldman to the directors of the Israel Association of Civil Rights (ACRI), May 1987 (ACRI files).

52. Of the five Jerusalem hospitals with obstetrics departments, two refuse to operate abortion approval committees and a third approves abortion only when continuation of the pregnancy poses significant risk to the mother. The remaining two hospitals, Hadassah Mt. Scopus and Hadassah Ein Karem, approve and perform abortions under all clauses of the law, but their approval process is long and cumbersome and the fees they charge are often higher than those charged by Tel Aviv hospitals. See Salzberger et al., "Patterns of Contraceptive Behavior" at 14 . 
resulted in intermittent political pressures during the 1980s for greater governmental control over committee decisions. Most of the attention was directed at the liberal abortion policies of six private hospitals in which, by $1988,66 \%$ of all approved abortions took place. ${ }^{53}$ The campaign against private hospital committees was originally initiated by a special advisor to the Minister of Health appointed under pressure from Agudat Israel, an ultra Orthodox religious party, to counteract what the party perceived as the overly liberal policies of the Ministry. His intervention resulted in the 1984 appointment of yet another abortion committee, the Committee for Uniformity in the Work of Committees for Termination of Pregnancy. Its report that year spoke of unspecified "problems" in the work of private hospital committees and recommended that all such committees be abolished because of the financial incentives that might have influenced the approval decisions of private hospitals..$^{54}$

The Committee for Uniformity's recommendation was transformed in 1987 into a draft bill that sought to abolish private hospital committees. The bill remained dormant for three years and resurfaced in 1989 in a version that promised governmental control over the authorization of all abortion-approving institutions by linking the licensing of committees in nongovernmental hospitals to the specific approval of the Ministry of Health. ${ }^{55}$ The proposed amendment was published in August 1989 and passed the first of three required readings in May 1990. Neither event aroused significant public interest, and both major parties, Likud and Labor, seemed willing to support the amendment, which, together with a set of other religiously inspired legislative proposals, became central to coalition negotiations.

Counter-mobilization efforts began in the spring of 1990 with the creation of a coalition of 15 women's and civil rights groups. The coalition initially focused its efforts on lobbying activities directed at both Likud and Labor Knesset members. It organized a public information campaign after Agudat Israel joined the government and pressures for final passage of the

53. Many of the abortions performed in private hospitals were, however, approved by government hospital abortion committees. Thus in 1988 private hospitals approved a total of 5,352 but performed 10,048 of the total of 15,255 legal abortions performed during that year. In 1989 there were 5,166 private hospital approval and 7,769 actual private hospital abortions out of a total of 15,216 legal abortions. Statistical Abstract of Israel, No. 42, sec. 3.25 (Central Bureau of Statistics, 1991).

54. Report of the Committee for Uniform Procedures in the Work of Committees for the Termination of Pregnancy, Letter from Prof. Yitzhak Shankar, committee chair, to Eliezer Shostak, Minister of Justice, 4 April 1984 (in Hebrew, ACRI files). Political efforts to amend the law and restrict abortions to hospitals designated by the Ministry of Health were attributed by an attorney for the Association for Civil Rights in Israel to a steady increase in the proportion of private hospital abortions during the 1980s. Neta Ziv Goldman, "Abortions at the Grace of the Coalition" (translated title), Ha'aretz, 11 June 1990, p. 4 (in Hebrew).

55. Draft Amendment No. 30 to the Criminal Code, 21 Aug. 1989. 
bill appeared imminent. ${ }^{56}$ Significantly, the campaign was billed as a struggle for reproductive health rather than reproductive rights and emphasized the potential medical risks of reductions in the number and accessibility of committees. The medical focus was a result of an explicit tactical decision to appeal to the greatest social consensus and to avoid what might have become a confrontational emphasis on abortion rights and the dangers of governmental monopoly over abortion services. The threat of such a monopoly was, however, the motivating factor behind the coalition's efforts and the reason it rejected a compromise proposal, brokered by a governmental advisor on women affairs, which would have increased the number of committees in public hospitals in compensation for the committees lost in the private sector. The coalition's own compromise proposal called for the substitution of private committees with committees based in the hospitals and clinics of the various sick funds.

The coalition's clear preference for nonconfrontational strategies and political compromise was the product of both internal divisions among coalition members and recognition of the limited public support for their cause. Financial support for the coalition largely came from two progressive American Zionist foundations. ${ }^{57}$ American Jewish groups also supported the coalition's efforts through a joint message signed by 12 religious and women's organizations. The communique, published in December 1990, urged Israeli leaders "not to risk women's lives in the interest of political expediency." In contrast to the conciliatory language and medical emphasis of the Israeli coalition's pamphlet, the American message spoke of "a woman's right to safe legal abortion" and referred to the proposed amendment as a threat to a "woman's right to privacy and confidentiality in making this most personal decision." 58

The coalition never had an opportunity to test its political strength. Before the amendment was put before the Knesset for final passage, the tide of Israeli politics shifted and the ultra Orthodox pressure waned. The amendment was tabled and the coalition, aware that its goal might not yet be achieved, suspended its activities. Private hospital committees continue to operate in the country, and committee diversity remains a crucial element in Israeli abortion practice. In addition, no enforcement efforts have been directed against the thousands of private, illegal abortions performed annually. While calls for stricter enforcement occasionally surface, primarily in response to media reports of medical malpractice, the police have been

56. Memo from Neta Ziv-Goldman (ACRI) to SHATIL, 6 Dec. 1990 (ACRI files).

57. The two foundations are the New Israel Fund and the Bronfman Fund. Fiscal report of the abortions coalition, 12 Dec. 1990 (ACRI files). It is significant that many of the constituent organizations of the coalition are themselves beneficiaries of the New Israel Fund, a liberal American Zionist fund which supports progressive social causes in Israel.

58. Joint communique regarding the proposed amendment to the abortions law, $24 \mathrm{Dec}$. 1990 (ACRI files). 
under little pressure to revise their hands-off policy in this area. As is often the case in this policy arena, ${ }^{59}$ legal norms continue to be marginal to the de facto arrangements guiding Israeli abortion compromises.

\section{FACADES, IMAGES, AND THE TERMS OF COMPROMISE}

The Israeli abortion compromise is the product of distinct separation between official messages and actual practices. The extralegal and informal nature of abortion policies in Israel is a constituent element in the implicit bargain governing this area. Ad hoc liberal abortion policies have always been accompanied in Israel by legal restrictions and public rhetoric that portrayed abortions as illegal, dangerous, and contrary to the religious values and demographic interests of the country. Supporters of legal access to abortion generally avoid public and media attention and rarely try to interfere with the abortion picture its opponents create. They shirk ideological confrontations and make little effort to initiate legal and political change in the abortion sphere. ${ }^{60}$ Perhaps even more important, few efforts are directed toward providing women with information regarding their rights under the law and their options for navigating the committee systems. While pregnancy counseling centers in most major cities aid in the dissemination of such information, women who lack access to such centers often choose private, and potentially less safe, abortions out of the misconception that legal abortions are difficult to obtain.

This passivity appears to be rooted in concern over the delicate balance that currently supports practical accommodations on abortion, as well as the place of a facade of legal and political restrictions in the prevention of direct conflicts between secular and religious law. Because abortion practice is always hidden from the public eye, it is less likely to result in the open confrontations that more visible religious affronts have triggered in Israel. Protection of this facade appears to have been a prominent factor in the reluctance of abortion service providers and supporters to draw attention to the reality of abortion practice in the country. Recognizing that such attention is more likely to harm than aid their cause, women's and civil rights groups have entered the abortion debate only in response to explicit threats to the status quo, such as the proposed amendment to the law discussed above. Otherwise, abortion policies appear to be shrouded in an air of secrecy aimed at preserving the gap between image and reality. ${ }^{61}$

This approach has, for the most part, successfully deflected greater religious pressure for abortion restrictions. Legislative gains such as the aboli-

59. See, e.g., Stanley K. Henshaw, "Induced Abortion: A Worldwide Perspective," 18 Family Planning Perspectives 250 (1986).

60. Amir \& Navon, Politics of Abortion 76-77 (cited in note 22).

61. Id. at 73 . 
tion of the social clause provision provided Orthodox parties with symbolical political victories and eased rabbinical demands to make abortion a central element in their political agenda. The abolition of the clause that allowed abortions for reasons unrelated to the health of the woman or fetus also brought the law closer to Jewish religious norms. Finally, in light of the fact that Orthodox women do procure abortions, a push for actual as opposed to formal limitations on abortion could be controversial among the religious parties' own constituencies. ${ }^{62}$

For these and perhaps other reasons, abortion opponents have stuck to their side of the implicit bargain and have refrained from escalating the conflict through direct targeting of abortion patients or providers. ${ }^{63}$ In sharp contrast to the prevalence of personal violence in the American abortion scene, the Israeli opposition has restricted its activities to the level of public demonstrations and legislative maneuvers.

Israeli women seem to have, for the most part, benefited from the terms of the Israeli abortion compromise. While some women appear to lack information about their rights and options, most have learned to navigate through the system. Resentment of the committee process is tempered with appreciation of the funding offered for many approved abortions, and a largely safe private abortion market provides an alternative for those who out of ignorance or choice avoid hospital procedures. Although local abortion availability problems exist in some places, most notably Jerusalem, the small scale of the country diminishes the significance of this problem. While abortion choices are subject to legal controls, governmental restrictions are significantly less burdensome than the alternatives religious and demographic concerns could have instituted. Awareness of the threat of such alternatives has led abortion services activists to cling to the precarious and imperfect balance they have achieved and to avoid actions that might jeopardize the status quo.

Fear of rocking the boat and recognition of the centrality of perceptions to the quiescence of the abortion scene have stifled public debate on the issue. Although this tactic has generally succeeded in removing abortion policies from the main stage of Israeli politics, it has significantly limited the capacity of abortion activists to respond to negative political developments. Because the public arena has largely been abandoned to the opposition, there is little basis for grass-roots support and few options for political mobilization. When the need for such mobilization has arisen, as in the case of

62. Salzberger et al., "Patterns of Contraceptive Behavior" at 31 (cited in note 28) report that in a sample of Jewish women who applied for pregnancy counseling in Jerusalem, $10 \%$ identified themselves as Orthodox or ultra Orthodox and $38.7 \%$ identified as traditional.

63. The director of Shilo, a Jerusalem pregnancy counseling center, stated that although her office has received publications from Efrat, the major abortion opposition group in the country, it has never been the target of harassment or demonstrations. Interview with Joanne Zack-Pakes, 23 Jan. 1993. 
the proposed amendment to the law, the lack of public awareness and involvement was a significant obstacle. The call issued by opponents of the proposed elimination of private hospital committees for support from liberal Jewish American groups is indicative of the degree to which the issue remains outside the mainstream of Israeli concerns. Under the implicit terms of the Israeli abortion compromise this situation is unlikely to change soon.

In the absence of an internal Israeli debate on abortion, activists on both sides of the issue have taken their cues from American conceptions of this dispute. This process has been greatly facilitated by the disproportionate presence of American immigrants among the staff and leadership of organizations active in this area. As indicated earlier, feminists from the United States were instrumental during the 1970s in the initiation of abortion legislative reforms, and Orthodox American immigrants during the 1980s have been responsible for political pressures for abortion restrictions. Pregnancy counseling centers with opposing orientations are run by American expatriots, and financial support for most abortion-related organizations comes, at least in part, from American Jewish sources. The result is an abortion arena that is both overshadowed by, and infused with, the passions of U.S. abortion struggles. ${ }^{64}$

The dependence of Israeli abortion activism on the ideological sustenance provided by the American model is significant for two distinct reasons. Because key players in Israel derive their commitments from American visions of the abortion controversy, American images of the dispute threaten to destabilize Israeli abortion policies. While thus far the American abortion experience seems to have inspired more caution than extremism in Israel, its divisions have begun to define the range of normative alternatives to current compromises.

But if the undercurrent of American influence can explain why, despite the general indifference of Israelis, abortion solutions remain precarious, it also underscores the distance of abortion policy issues from the core concerns of most Israelis. Because the Israeli abortion debate is largely an imported controversy with little local resonance, the compromises it engendered have been forged over much narrower splits than the normative divisions American abortion compromises would need to bridge. Recognition of this difference should alert us both to the social contingency of the American focus on abortion as a uniquely tragic dilemma and to the implications

64. Israeli abortion activists are deeply cognizant of the potential impact of developments in the American abortion sphere on the evolution of Israeli abortion politics. Following the U.S. Supreme Court's decision in Webster v. Reproductive Health Services, the secretarygeneral of Na'amat, the women's arm of the Histadrut, Israel's mega trade union, voiced concern over the potential impact of the decision on anti-abortion forces in Israel. In a letter addressed to labor zionist organizations in the United States, the secretary-general encouraged these groups to "add their political muscle" to the American pro-choice struggle. Judy Siegel, 'Na'amat Fears Israeli Fallout from U.S. Ruling on Abortion," Jerusalem Post, 6 July 1989, p. 2. 
of this distinction for cross-national adoption of legislative compromises in this area.

\section{CONCLUSION}

The divergent paths of abortion politics in Israel and the United States reflect important differences in underlying religious doctrines, geographical size, and feminist ideologies, as well as the immediacy of other social cleavages in the two countries. But perhaps more profoundly, the two abortion stories are the product of distinct understandings of the mutual obligations between citizens and their state and of the relationship between individual and collective rights and duties. These differences are reflected by activists on both sides of the abortion issue in the two countries. Israeli and American supporters of abortion rights made opposite trade-offs between abortion funding and regulation, while abortion opponents focused on divergent claims: fetal rights in the American case, and demography and collective identity in the Israeli case. Though the diffusion of American ideology has had some superficial impact on the rhetorical stands of both sides in Israel, it has not altered the distinct starting points of abortion controversies in the two countries.

In contrast to the United States, where the abortion dispute has been played out against a wall of separation between church and state, the Israeli abortion story is a chapter in a much larger debate over the meaning of the state's Jewish identity. Abortion is a singular dilemma for Americans because the normative questions it raises directly challenge prevailing liberal commitments to the moral neutrality of the state. Unlike Americans, Israelis live within a political system in which the state maintains an intimate presence in the life of its citizens and collective formulations of identity and norms are defining features of public discourse. Thus, unlike the United States where abortion invokes dormant fundamental divisions, in Israel it is politics as usual. 65 Such normalcy means both a distinct preference for ambiguity and the subordination of religious conflicts to the increasingly urgent debate over the future of the occupied territories. As gradual pressures for Israeli constitutional reform converge with fragile signs of peace and hopes for drastic realignment of political priorities, long-postponed debates about the boundaries between private and public domains are likely to emerge. It remains to be seen whether a more contentious abortion scene would be one of the manifestations of this evolving social context and growing Israeli concern with the trade-offs between community consensus and the right to be left alone.

65. The "politics as usual" baseline is derived from Kim Lane Scheppele, "Abortion and the Breakdown of Politics-as-Usual" (presented at Law \& Society Association annual meeting, Philadelphia, 1992). 
Heinonline -- 19 Law \& Soc. Inquiry 3361994 